\title{
ReSEARChArTicle
}

\section{Character association and path co-efficient analysis in Kharif onion (Allium cepa L.) genotypes}

\author{
AKANKSHA SHARMA, SHIV CHANDRAKAR AND DINESH KUMAR THAKUR
}

\begin{abstract}
SUMMARY
Correlation and path co-efficient analysis for bulb yield and its components were estimated in 28 genotypes of Kharif onion (Allium cepa L.) along with a check i.e. Agrifound Dark Red. The studies indicated that out of 11 characters, total yield (t/ha) showed positive and significant association with plant height, number of leaves/plant, collar height, collar girth, leaf length, equatorial diameter of bulb, average weight of bulb and marketable bulb yield indicating that an intense selection for these characters improve bulb yield in onion. Path co-efficient analysis revealed that marketable bulb yield, average weight of bulb, number of leaves/plant, collar height and leaf length showed positive direct effect on total yield, whereas plant height, collar girth and equatorial diameter of bulb showed positive indirect effect on total yield via marketable bulb yield.
\end{abstract}

Key Words : Onion, Correlation, Path co-efficient analysis

How to cite this article : Sharma, Akanksha, Chandrakar, Shiv and Thakur, Dinesh Kumar (2015). Character association and path coefficient analysis in Kharif onion (Allium cepa L.) genotypes. Internat. J. Plant Sci., 10 (1): 70-73.

Article chronicle : Received : 04.11.2014; Revised : 30.11.2014; Accepted : 16.12.2014

$\longrightarrow$ MEMBERS OF THE RESEARCH FORUM

Author to be contacted :

AKANKSHA SHARMA, Department of Horticulture, Indira Gandhi

Krishi Vishwavidyalaya, RAIPUR (C.G.) INDIA

Email: akanksha23.in@gmail.com

\section{Address of the Co-authors:}

SHIV CHANDRAKAR, Department of Agronomy, Navsari Agricultural University, NAVSARI (GUJARAT) INDIA

DINESH KUMAR THAKUR, Department of Genetics and Plant Breeding, Indira Gandhi Krishi Vishwavidyalaya, RAIPUR (C.G.) INDIA 